\title{
Vernaküler ve Çağdaş Mimarlık Örneklerinin Sürdürülebilirlik Bağlamında Karşılaştırmalı Analizi: Antalya Kaleiçi ve Deniz Mahallesi Örneği
}

\author{
Fatih CANAN1 ${ }^{(D)}$, Hande Büşra KOBYA*2 ${ }^{\circledR}$, Ayten Begüm AKÖZ3 ${ }^{\circledR}$, Aliye TEMİZCí4 \\ 1,2,3,4Konya Teknik Üniversitesi, Mimarlık Fakültesi, Mimarlık Bölümü, 42150, Konya, Türkiye
}

(Alınış / Received: 30.11.2019, Kabul / Accepted: 29.04.2020, Online Yayınlanma / Published Online: 20.08.2020)

Anahtar Kelimeler

Geleneksel-Çağdaş, Vernaküler mimarlık, Kimlik
Özet: Vernaküler mimarlık, iklimsel verileri ve arazi yapısını dikkate alan, insan konforuna önem veren, yöreye özgü malzemelerin ve yapım yöntemlerinin kullanıldığı, çevreye uyumlu, sürdürülebilir bir tasarım bütünü olarak bugün önemini korumaya devam etmektedir. Süreç içinde sanayileşme, hızlı nüfus artışı gibi nedenler ile birlikte artan konut alanları ise bugün çevre verilerden bağımsız şekilde gelişim göstermektedir. Yapılacak olan çalışmada, vernaküler mimari özelliklerinin görüldüğü Antalya Kaleiçi yerleşimi ile bu yerleşime yakın konumdaki, 1950 yılı sonrası imar planlı konutların yer aldığı Deniz Mahallesi, sürdürülebilir özelliklerin tespit edilmesi amacıyla karșılaștırılmıștır. Yapılan karșılaștırma literatürdeki yaklașımlar üzerinden yerleșim ve yapı ölçeğinde gerçekleştirilmiştir. Elde edilen bulgularda Kaleiçi yerleşiminin çevre faktörlerinin göz önüne alınarak düzenlendiği, Deniz mahallesinde ise günümüz yapım tekniklerinin kullanıldığı ancak pek çok çevresel faktörünün dikkate alınmadan konut dokularının oluşturulduğu gözlenmiștir. Çalışmanın sonucunda; geleneksel mimarinin çağdaş konutlara göre daha konforlu ve daha sürdürülebilir özelliklere sahip olduğu ve gelecek planlamalarda bu durumun dikkate alınarak tasarım yapılması gerekliliği ortaya konulmuştur.

\section{Comparative Analysis of Vernacular and Contemporary Architecture Examples in the Context of Sustainability: The Case of Antalya Kaleiçi and Deniz Neighborhood}

\section{Keywords}

Traditional-Contemporary, Vernacular architecture, Identity

\begin{abstract}
Vernacular architecture continues to maintain its importance as a sustainable design whole, which takes into consideration the climatic data and the land structure, cares about human comfort, and is compatible with the environment, where local materials and construction methods are used. Increasing residential areas due to industrialization and rapid population growth in the process, however, are developing independently from environmental data. In the study to be carried out, Antalya Kaleiçi settlement, where the vernacular architectural features are seen, and Deniz neighborhood, where the housing planned housing after 1950 are located close to this settlement, were compared in order to determine sustainable properties. Comparison made on the scale of settlement and structure through the approaches in the literature. In the findings obtained, it was observed that the Kaleiçi settlement was arranged taking into consideration the environmental factors, while today's construction techniques were used in the Deniz neighborhood, but housing textures were created without taking into account many environmental factors. As a result of the study; traditional architecture has more comfortable and more sustainable features than contemporary residences and it has been demonstrated that it is necessary to design by taking this situation into consideration in future planning.
\end{abstract}




\section{Giriş}

Yapı sektörü yeryüzünde çevresel etkiler meydana getiren önemli insani aktiviteler arasında yer almaktadır. Yapı sektörünün çevreye verdiği olumsuz etkilerin azaltılması için sürdürülebilir mimari yaklaşımların uygulanması bir gereklilik durumuna gelmiştir. Binalarda fosil kökenli yakıt kullanımlarının sınırlandırılması, yenilenebilir enerji kaynaklarının ve gömülü enerjisi düşük yapı malzemelerinin kullanımının sağlanması için yenilikçi tasarım yaklaşımları geliştirilmeye çalışılmaktadır. Bunların arasında, "Gelenekselden ve geçmişten öğrenme başlığı" altında incelenebilecek yaklaşımlar da yer almaktadır. Bu bağlamda vernaküler mimarlık, sıkça başvurulan bir bilgi edinme kaynağı olmuştur. Vernaküler mimarlık, deneme yanılma ile yıllar içerisinde oluşmuş, doğayla barışık mimari çözümleri bünyesinde barındırmaktadır.

Doğal koşullar, kültür, yerel yapı malzemeleri ve teknikleri, dünyanın farklı coğrafyalarında vernaküler mimarinin oluşumunda etkili olan temel girdiler olmuştur. Bunlar, sınırlayıcı olduğu kadar, mekânsal ve yapıya ilişkin teknik sorunların çözümünde yaratıcılığın gelişimini de sağlamıștır. Bir yerin doğal özelliklerini, öncelikle iklimsel koşullar, bitki örtüsü ve topoğrafya belirlemektedir. Benzer iklimsel özelliklere rağmen, dünyanın çok farklı coğrafyalarında yapı üretim şekillerinde benzerlikler kadar farklılıklar da görülmektedir. "Doğaya dokunma" ve ona müdahale etme biçimlerinde görülen çeşitlilikte, kültürün de rolü bulunmaktadır. Toplumsal değerler, doğayı algılama biçimlerini ve doğa-insan ilişkilerini de belirleyerek yapılı çevrelerin oluşumunu etkilemektedir.

Vernaküler mimarlık, uzun yıllar içinde yapı üretim pratiklerinde ortaya çlkan tutucu bir tavır değildir. Üstesinden her zaman gelinemeyen zor coğrafi koşullar veya sınırlı ekonomik durumlar, vernaküler mimarinin uzun dönemler içerisinde yavaş seyreden değişimlerine neden olmuştur [1]. Yapı üretim pratiğinde, bu nedenle her zaman çok seçenek olmamıştır. Ancak kısıtlamalar, bölgelere göre değişkenlik gösteren bilgece çözümlerin üretilmesini de sağlamıştır.

Batı'da modernizmin gelişim döneminde, vernaküler mimariye olan ilgi yok denecek kadar az olmuştur. Çünkü vernaküler mimarinin, gelişme fikri ile tezatlık içinde olduğu, yoksulluğu ve az gelişmişliği temsil ettiği düşünülmüştür. Alvar Aalto, Frank Llyod Wright ve Luis Barragan gibi ün yapmış az sayıda mimar, modern mimarlığın söylemlerine ters düşmeden bölgeye ait iklim, kültür gibi unsurları mimari tasarımlarına katmaya çalıșmışlardır. Ancak genel anlamda 1970'lere kadar, modern mimaride bölgesel yaklaşımların var olduğunu söylemek çok mümkün olmamıştır [2]. Enternasyonalist mimari anlayışın (uluslararasıcılık) zirveye ulaştığı 1964 yılında, Bernard Rudolfsky, New York Modern Sanat Müzesi'nde "Mimarsız Mimari" başlıklı bir sergi düzenleyerek, unutulmuş ve değer verilmemiş bir mimariyi büyük kitlelere tanıtmıștır [3]. Bu sergi sayesinde "mimarsız mimarlık" konusuna akademik araştırmalarda yer verilmeye başlanmıştır. Mimarlığın bir konusu olarak görülmeye başlanan bu alana, vernaküler mimarlık denmeye başlanmıştır.

Mimarlık camiasında büyük ilgi gören "mimarsız mimarlık" sergisinin gerçekleştiği tarihin hemen öncesinde ve takip eden yıllarda, global çevre sorunları çeşitli yayın ve gerçekleştirilen toplantılarla dikkat çekmeye başlamıștır. 1960'lı ve 1970'li yıllar, çevre sorunlarının ele alınışı bakımından önemli yıllar olmuştur. İşte bu yıllarda, çevresel ve toplumsal olaylarla ilgili önemli gelişmelerin olduğu bir ortamda, vernaküler mimarlığa olan ilgi de artmaya başlamıştır. Vernaküler mimarlığın araştırılması sonucu elde edilecek bilgilerle, güncel, çevresel ve toplumsal problemlere çözümlerin üretilebileceği düşünülmüştür. İklim, malzeme/yapım tekniği ve kültür gibi bir yere ait temel verilerin, ev mimarisinde ne denli başarılı bir şekilde dikkate alındığı, araştırma sonuçlarından elde edilen en önemli ortak bulgu olmuştur.

Günümüzde son dönemlerde dünyanın farklı iklim kuşaklarında var olan vernaküler mimarlık keşfedilmeye devam edilmektedir. Gerçekleştirilen çalışmalarda, amaçlar ve yöntemler bakımından çeşitliliğe rastlanmaktadır. Bunların önemli bir bölümünde var olan enerji simülasyon programları yardımı ile veya sadece hesaplama yöntemleriyle bir yöreye ait geleneksel bir konutun enerji performansları belirlenmektedir $[4,5,6]$. Zhai ve ark. (2010) çalışmalarında yeryüzündeki farklı iklim tiplerinin bir sınıflandırmasını yaparak bu iklimlerde belirlenen belli bir sayıdaki temsili vernaküler mimarlık örneklerinin enerji performanslarını belirlemişlerdir. Ayrıca farklı iklim tiplerinde yer alan vernaküler konut mimarisi için optimal yapım teknikleri için öneriler sunmuşlardır [5].

Vernaküler mimariden öğrenilen detay ve tekniklerin çağdaş yapılarda yorumlanarak ve geliştirilerek uygulanmasına yönelik önerilerin geliştirilmesi, rastlanan başka bir kategorideki araştırmalardır [7, 8, 9]. Psiko-sosyal boyutta, Bosman ve Whitfield (2015) tarafından gerçekleștirilen "Perceptions of vernacular architecture" isimli çalışma örnek olarak incelenebilir [10]. Güncel bir mimari tasarıma, vernaküler mimarlık ilkelerinin rehber olması istendiğinde, insan algı psikolojisinden faydacı bir yaklaşımla nasıl yararlanabileceği, Güney Afrika koşullarında ele alınmaktadır.

En çok rastlanan çalışma türleri içerisinde karșılaștırmalı çalıșmalar önemli yer tutmaktadır [11, 12]. Fernades ve ark. (2014) gerçekleştirdikleri çalışma, bu türdeki araştırmalar için örnek teşkil 
edebilir. Çalışmada, Akdeniz iklim kuşağında yer alan Portekiz'in güneyindeki Évora kenti ile Mısır'ın kuzeyindeki İskenderiye kenti ele alınmıştır. Uzak mesafeye ve farklı kültürlere rağmen, bu yörelerdeki vernaküler mimaride ve geleneksel kent dokularında benzer mekânsal çözümler belirlenmiştir [11]. Al Tawayha ve ark. (2016) ise Filistin'in Nablus kentinde geleneksel ve yeni kent dokusunu niteliksel bir yöntemle karşılaştırmış, güncel tasarımlar için öneriler sunmuşlardır [12].

Tüm bu araștırmalardan yola çıkarak, çalışma kapsamında, Antalya kent merkezindeki geleneksel dokuya sahip vernaküler mimari özelliklerinin görüldüğü Kaleiçi Bölgesi ve bu bölgeye yakın konumda bulunan 1950 sonrası imar planlı dönemlerde inşa edilmiş konutların yer aldığı Deniz Mahallesi'nin yerleşim ölçeği ve yapı ölçeğinde karşılaştırılması ile bu alanların hangisinin daha sürdürülebilir ve yaşanabilir olduğunun tespit edilmesi amaçlanmaktadır. Yapılan çalışma, vernaküler mimarinin, modern mimari yaklaşımlara örnek olması, çağdaş yapım özellikleri ve çeşitli ekolojik yöntemlerin çağdaş konutlarda yeniden ele alınması, günümüz ve gelecekte çevreye duyarlı, sürdürülebilir mimari yaklaşımların geliştirilmesinde vernaküler mimarinin kaynak gösterilmesi ve öneminin vurgulaması dolayısıyla önem taşımaktadır.

\subsection{Ekoloji Kavramı ve Vernaküler Mimarlık İlişskisi}

Sanayileşme ile birlikte kırsaldan kente olan göçler artmış, bu durum kentte yapılaşmanın artmasına ve yeşil alanların azalmasına sebep olmuştur. Kentsel yeşil alanların azalması, hava kalitesinin olumsuz yönde değişimini, kentsel ısı adası etkisinin artmasını ve çevre kirliliğini beraberinde getirmiştir. $\mathrm{Bu}$ durumun sonucunda ekolojik mimarlık kavramı ortaya çıkmış ve bu olumsuz durumların önüne geçilmesi amaçlanmıştır.

Ekolojik mimarlık, diğer adıyla sürdürülebilir mimarlık, mevcut arazi verileri, iklimsel veriler ve doğal çevre göz önünde bulundurularak bir mimari yapının yerleşiminde, tasarımında ve malzeme seçiminde yapının enerji ihtiyacının en aza indirgenmesi ile çevreye en az etkisi olan binaların tasarlanmasıdır [13]. Bu binaların tasarımında ise yerel veriler (topografya, iklim, doğal çevre) ve canlı yaşamı esas alınarak, tüketilen enerjinin en aza indirilmesi ve tasarruf sağlanması amaçlanmaktadır. Topografya, bitki örtüsü, iklim koşulları gibi doğal veriler ve sosyal, kültürel, ekonomik özellikler gibi faktörlere bağlı olarak ortaya çıkan yapılar maksimum verimlilikte enerjinin elde edilmesi ve uygun konfor koşullarının sağlanmasıyla ekolojik mimariye örnek olmaktadır. Bu bağlamda, vernaküler (yerel) mimarlık biçimlenişi ekolojik mimarlığın önemli bir parçasını oluşturmaktadır.
Yerel mimarlık, diğer bir deyişle vernaküler mimarlık, nesiller arasında sürekli bir iletişim sağlayan [14], yerel iklim koşullarını dikkate alarak, yöreye özgü malzemeleri ve basit ve geleneksel yapım tekniklerini kullanarak o bölgede yaşayan insanların geleneklerine, yaşam tarzlarına ve ekonomik koşullarına uygun bir şekilde birleştiren, estetikten ve süsten oldukça uzak bir tasarım bütünü olup anonim mimarlık veya insanlığın mimarisi olarak da tanımlanmaktadır $[15,16,17]$.

Türkiye'de vernaküler mimarlık ile ilgili araștırmalar 19. yüzyıl sonu ve 20. yüzyıl başlarında artış göstermiş [18], Anadolu'da vernaküler mimarlığın gelişmesinde, çeşitli uygarlıkların varlığı, iklim bölgelerinin ve topografyanın farklılığı, kültürel ve sosyal değişimler etkili olmuş, bu bağlamda vernaküler mimarlık özelliklerini gösteren "Batı Anadolu'da Geleneksel Konut" kavramı ortaya çıkmıştır $[13,19]$. Bu konutların çevre verilerinin dikkate alınarak oluşturulmuş olması yapıların sürdürülebilirlik anlamında önemli örnekler olmasını sağlamış, bu dönemden sonra bu konut yapılarının korunması ve yeniden işlevlendirilmesi ile ilgili çalışmalara başlanmıştır.

\subsection{Vernaküler Mimariyi Etkileyen Faktörler}

Vernaküler mimarlık örnekleri iklim, topografya, güneșlenme yönü, rüzgâr yönü gibi farklı koşullardan etkilenerek oluşum göstermektedir. Bu koşullar, kentsel doku ve yapı ölçeğinde biçimlenmeyi etkilemiştir. Vernaküler mimarlık örnekleri incelendiğinde yapıların, güneş, rüzgâr gibi iklimsel faktörlerden en verimli biçimde yararlanılması amacıyla, birbirinin manzarasını kapatmayacak şekilde topografyaya uygun yerleşim gösterdiği görülmektedir. Bu durum konforlu, sürdürülebilir iç ve dış mekânların oluşumunu sağlamakta olup, yöresel mimarlığı şekillendiren en önemli etkenlerden biri olarak öne çıkmaktadır.

Sıcak iklim bölgelerindeki yerleşimlerde biçimlenme dışa daha açık bir planlama anlayışı gerektirirken, soğuk iklim bölgelerinde ise biçimlenme dış çevreye daha kapalıdır [20]. Rüzgârın yönü ve şiddeti binaların yönlenmesinde oldukça önem taşımaktadır. Bir aks üzerine sıralanmış yapılar arasında hava sirkülasyonu yeterince iyi sağlanamazken, şaşırtmalı olarak konumlanmış yapıların yer aldığı yerleșimde ise sirkülasyon çok daha iyi bir şekilde sağlanabilmektedir [21]. Binanın formu da güneş ışınımlarından faydalanmak için oldukça önem taşımaktadır. Bina ne kadar kompakt ise yüzeylerde o kadar az ısı kaybı gerçekleşmektedir [22]. Bitki örtüsü ise binaların yerleşim düzenlerini, yönelimlerini ve malzeme kullanımlarını etkilemektedir. Yeşil alanların varlığı, hava kalitesinin iyileștirilmesi, kentsel ısı adası etkisinin azaltılması ve gölgelenme sağlanmasının yanında bölgedeki 
seslerin yalıtılmasını ve dolayısıyla daha konforlu mekânların oluşmasını sağlamaktadır [23].

Yerel mimarlık tarihsel süreç içinde deneme-yanılma yöntemi ile gelişim ve değişim gösteren bir olgu olduğu için zaman içinde yaşanmış olaylardan da etkilenmiştir. Geçmişte yaşanan olaylar, o dönem içindeki alışkanlıklar, savaşlar, politika vb. olaylar yöresel mimarinin gelişim ve değişiminde etkili olmuştur [24]. Bireylerin farklı alışkanlıklar ve kültür düzeylerine sahip olması farklı planlama anlayıșlarını beraberinde getirmiștir. Yerel mimarlıkta, o yerleşimde yaşayanların sosyo-ekonomik özellikleri de konutların yapımını etkilemiştir. Yöre halkının kendi imkânları ile yaptığı bu binalarda, en ucuz, en verimli ve en kolay ulaşılabilir malzemelerin kullanılması, hiçbir malzemenin israf edilmemesi, ileriki dönemlerde malzemenin bakım gerektirmemesi tercih sebebi olmuştur. Bu durum, hem taşıma hem de malzeme maliyetinden tasarruf edilmesini sağlamıștır.

\section{Materyal ve Metot}

Çalışmada; sokakları, yapıları ve sahip olduğu geleneksel konut dokusu ile Antalya'nın kent merkezini oluşturan Kaleiçi yerleşimi ve farklı konut tipolojisine sahip apartman ve konutların yer aldığı Deniz mahallesi üzerinden karşılaştırılmalı bir analiz yapılmıștır. Çalışmada ele alınan Deniz Mahallesi, kentin giderek yayılımı ve surların dışına çıkması ile birlikte 1950 sonrası imar planlı olarak gelişmiş bir alanda yer alması, Kaleiçi yerleşimi ile benzer iklim özelliklerinin görülmesi ve çağdaş yapım sistemlerinin uygulandığı bir alan olması dolayısıyla seçilmiştir. Yapılan analizlerde yerinde gözlem yapılmış, fotoğraflama ve haritalama tekniklerinden yararlanılmıştır.

Analizlerde yerleşimin kimliğini öne çıkaran ve dokunun sürdürülebilirliğini ölçmede etkili olacak parametreler, diğer araştırmacıların yaptığ çalışmalar üzerinden derlenerek oluşturulmuştur. Bu parametreler yerleşim ölçeğinde; kentsel düzen ve sokak dokusu, yapı-sokak ilişkisi ve yeşil dokudur. Yapı ölçeğinde ise; bina formu, mekânsal kullanım ve organizasyon, bitkilendirme ve su elemanı kullanımı, bina kabuğu ve yapı malzemesidir (Tablo 1).

Tablo 1. Seçilen bölgelerin karşılaştırılmasında kullanılacak parametreler

\begin{tabular}{|l|l|}
\hline \multicolumn{1}{|c|}{ Yerleşim Ölçeği } & \multicolumn{1}{|c|}{ Yapı Ölçeği } \\
\hline -Kentsel düzen ve & -Bina formu \\
sokak dokusu & -Mekânsal kullanım ve \\
-Yapı-sokak ilişkisi & organizasyon $\quad$-Bitkilendirme ve su \\
-Yeşil doku & elemanı kullanımı \\
& -Bina kabuğu \\
& -Yapı malzemesi \\
\hline
\end{tabular}

Kaleiçi ve Deniz mahallelerinde analizler yerinde gözlem ile yapılmış, fotoğraflama ve haritalama tekniklerinden yararlanılmıştır. Yapılan analizler ile elde edilen bulgular ise karşılaştırma yöntemi ile yorumlanmıştır.

\subsection{Kaleiçi ve Deniz Mahallesi'ne ilişkin bilgiler}

Antalya, Akdeniz bölgesinin batısında, Isparta, Burdur, Muğla ve Mersin kentlerine sınır olan bir kıyı yerleşimidir. Antalya kenti doğu-batı yönünde uzanmış olup, kıyılar turizm amaçlı yoğun kullanıma sahiptir. Kaleiçi ve Deniz Mahallesi ise Antalya kent merkezinde yer almakta olup denize yakın konumlanmış alanlardır (Şekil 1).

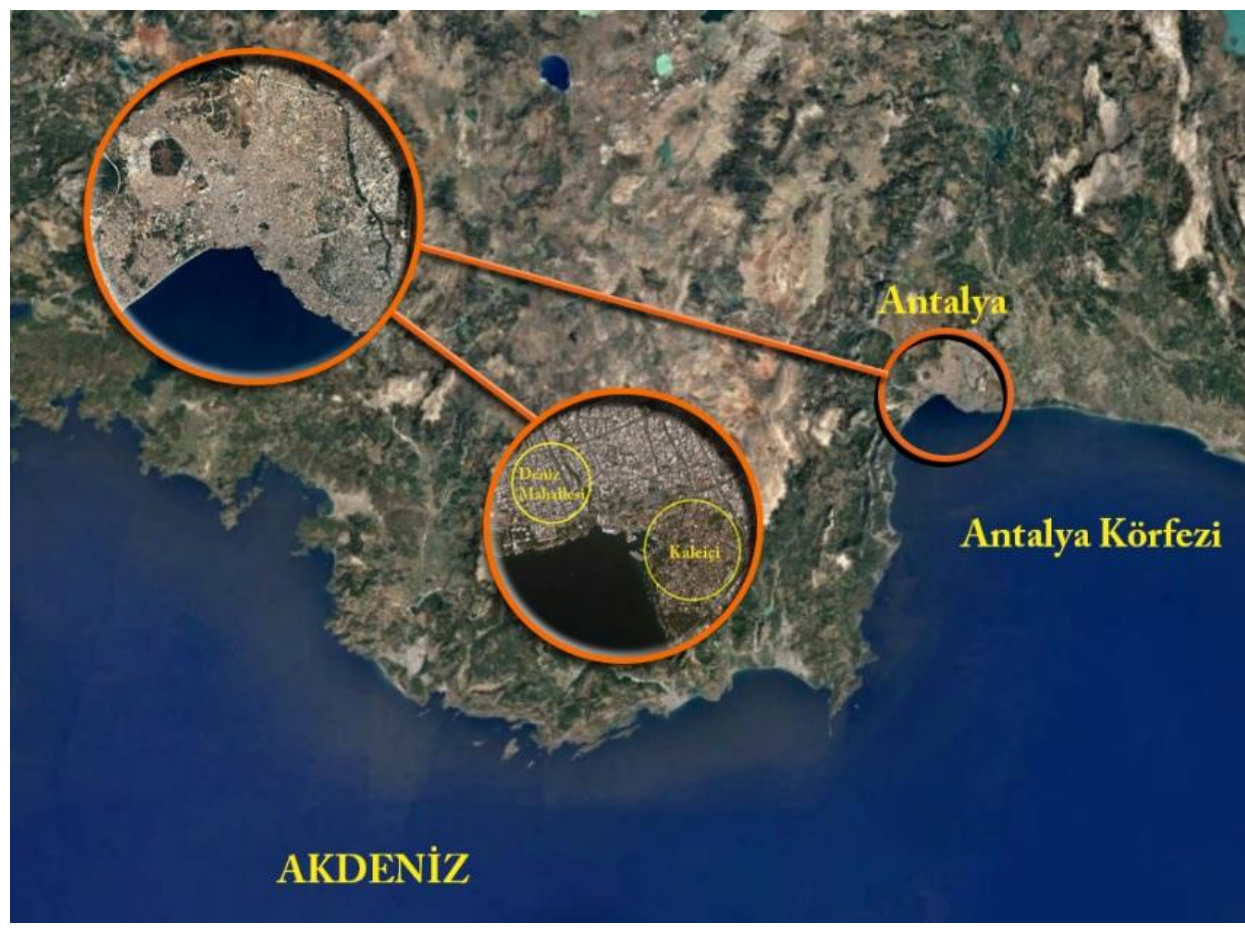

Şekil 1. Kaleiçi ve Deniz Mahallesinin Coğrafi Konumu. 

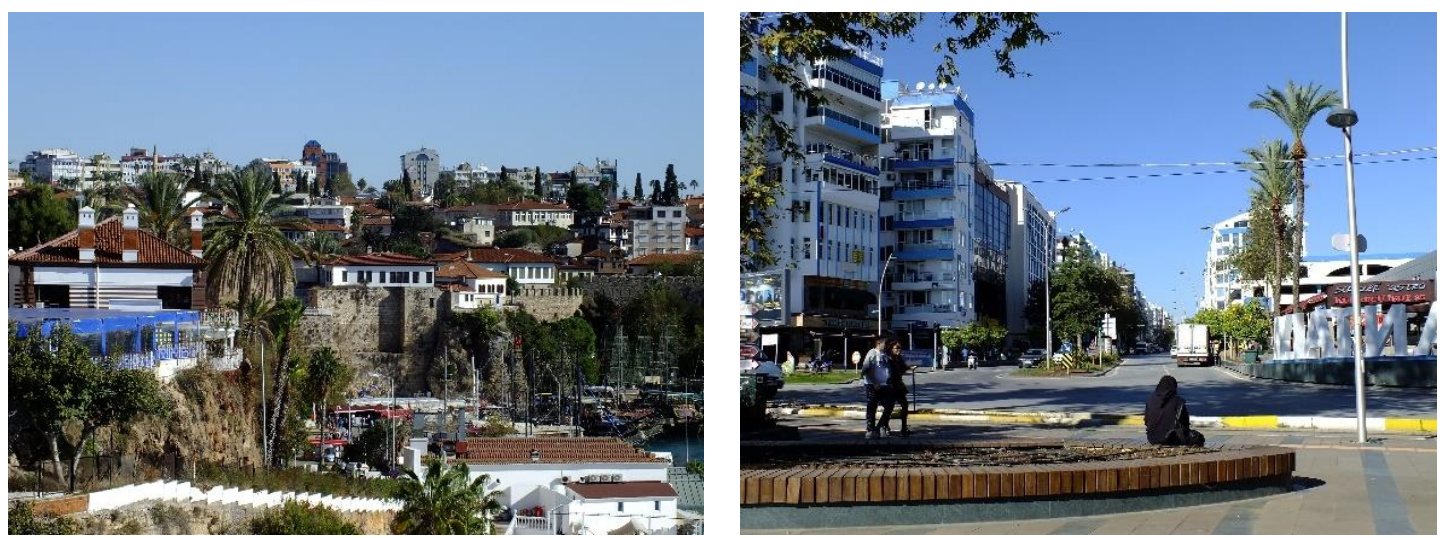

Şekil 2. Topografik yerleşim / Solda Kaleiçi, sağda Deniz mahallesi Anafartalar caddesi [26].

Antalya'nın genel iklim özelliklerine bakıldığında yazlar sıcak ve kurak, kışlar ılık ve yağışlı geçmektedir. Yazın ortalama sıcaklık 30-34 derece arasındadır. Kışın ise sıcaklık ortalama 9-15 derece arasında değișmektedir. Kentte kar ve don gibi meteorolojik olaylar neredeyse hiç görülmemektedir. Ylllık ortalama nispi nem ise \%64 civarındadır [25]. Nem oranı ve sıcaklığın yüksek olması yașam konforunu olumsuz etkilemektedir. $\mathrm{Bu}$ nedenle havalandırma amaçlı bir hava sirkülasyonuna ihtiyaç duyulmakta, dolayısıyla kentte esen rüzgârlar önem tașımaktadır. Antalya'nın hâkim rüzgârı ise, güney ve güneydoğu yönlerinden esen meltem rüzgârı ile kuzeydoğu yönünden esen poyraz rüzgarıdır [13]. Meltem rüzgârının serinletici etkiye sahip olması nedeniyle bu rüzgârdan olabildiğince faydalanmak amaçlanmaktadır.

Kültürel özellikler ile birlikte doğal/yapay çevre özellikleri ile şekillenen Kaleiçi yerleşimi bugün sahip olduğu konut dokusuyla özel bir yerleşim olmuş, kentsel sit alanı ilan edilmiştir. Aynı iklim özelliklerinin görüldüğü Deniz Mahallesi ise topografya, kültür vb. etkilerle birlikte modern yapım yöntemlerinin kullanıldığı konut dokuları ile farklılaşma göstermiştir. Kaleiçi yerleşimi oldukça eğimli bir topografya üzerinde yer almakta olup denize doğru yönelim göstermektedir. Deniz mahallesi ise falezler üzerinde düze yakın bir topografyada yer almaktadır (Şekil 2).

\section{Bulgular}

\subsection{Yerleşim ölçeğinde yapılan analizler}

Kentsel Düzen ve Sokak Dokusu: Antalya'nın tarihi kimliğini yansıtan Kaleiçi, surlarla çevrili olarak planlanmıştır. Denize dik doğrultuda oluşum gösteren ana akslardaki sokak yapılanması ve onlara bağlantılı organik șekillenen sokak örüntüsüne sahip bu konut bölgesi (Şekil 3) günümüze kadar sürdürülebilir yapısal niteliğini yansıtabilen bir kent yerleşimidir. Antalya'nın bölgesel iklim özelliklerinin getirisi olan yoğun sıcaklık ve nem oranı sebebiyle serinletici havaya olan ihtiyaç, organik sokak ağlarının oluşturduğu yönde koridor görevi yaparak bölgede serin havanın dolaştırılmasına imkân vermektedir. Dar sokaklar ve yapıların bitişik nizamda planlanması güneş ışınlarının yapıya doğrudan ulaşmasını engelleyerek gölge mekân oluşumunu sağlamaktadır.

Ticari bir aks haline dönüşen Anafartalar caddesinin bulunduğu Deniz Mahallesi, maksimum manzara yönünden faydalanmak için sistematik bir gelişim göstererek gridal sistemde sokak yapısına sahip bir kent formunda planlanmıştır (Şekil 3). Gridal sitemin en belirgin özelliklerinden olan doğrusal akslardaki sokaklarla araç ve yaya sirkülasyonu sağlanmaktadır. Rüzgâr, denize dik gelișen doğrusal sokaklarda, serinletici etkisini gösterebilmektedir. Ancak, gridal sistemin özelliği olarak ızgara tipi sokakların dik açılar ile kesişmesi rüzgârın sokaklar yardımıyla iletimini kesmektedir.
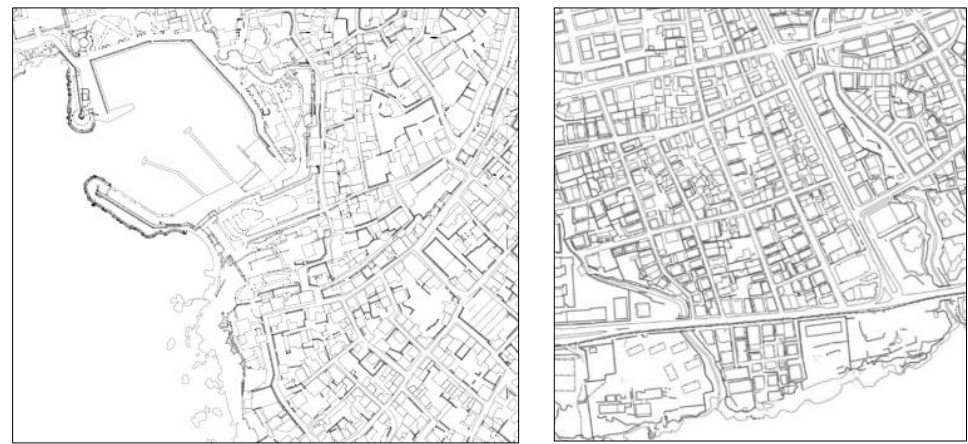

Şekil 3. Kentsel düzen ve sokak dokusu / Solda Kaleiçi, sağda Deniz mahallesi. 
Yapı-sokak İlişkisi: Batı Anadolu'da geleneksel konut örneklerinden olan Kaleiçi evleri genel olarak 2 katlı olup, içe dönük bir yapılanmaya sahiptir. Sokaklar, avlu duvarları ve/veya zeminde yer alan sağır ya da küçük pencere boşluklarının olduğu depo, ahır vb. mekânlar ile ilișki kurmaktadır. Güvenlik ve mahremiyet odaklı zemin kat sağır avlu duvarları oldukça yüksek yapılanmıştır (Şekil 4). Bu yapılanma ise sokaklarda bir koridor etkisi oluşturarak güneş ışınlarının kırılmasını ve gölgelemeyi sağlamış, termal konforu olumlu yönde etkilemiștir. Sokaklarda bulunan su arıkları ise yaz aylarında sokağa serinletici etki sağlarken, kış aylarında ise fazla yağmur suyunun taşınmasını sağlamaktadır.

Deniz mahallesinde ise yapilar genel olarak 5-8 katlıdır. Anafartalar Caddesi üzerindeki yapıların zemin katlarında yer alan ticari mekânlar, caddeye doğrudan açılmaktadır. $\mathrm{Bu}$ caddeye bağlanan sokaklar üzerinde ise genel olarak konut ișlevli yapılar yer almaktadır (Şekil 4). Yapıların yüksekliklerinin sokak veya caddelerin genişliğine olan oranının Kaleiçi'ne göre daha az olması nedeniyle gölgelenme yeterince sağlanamamakta, bu durum termal konforu olumsuz yönde etkilemektedir. Birbiri ile oldukça yakın konumlanmıș olan yüksek katlı konutların doğrusal bir aks halinde devam ettiği bu cadde ve bağlantılı sokakların sürdürülebilir tasarım anlayışıyla oluşturulmuş bir dokuya sahip olmaması, yapay iklimlendirme kaynaklarına ihtiyaç duyulmasını gerektirmiştir.

Kentsel Peyzaj Alanları: Kaleiçi'ndeki yeşil dokunun genel olarak konutların avlularında yer alan peyzaj elemanlarından oluştuğu gözlemlenmiștir. Kıyıdaki falezler üzerinde yer alan bitki örtüsü de Akdeniz ikliminde yetişebilen ağaçlar açısından oldukça zengindir.

Deniz Mahallesi'nde ise Anafartalar Caddesi'nin güneyindeki Yavuz Özcan Parkı dışında yeşil alanların oldukça az bulunduğu dikkat çekmektedir. Deniz mahallesinde, yapılaşmanın fazla olması, bu alandaki yeşil doku yoğunluğunun az olmasına neden olmuştur. İki bölgedeki kentsel yeşil alanların karşılaştırması aşağıda verilmektedir (Şekil 5).

\subsection{Yapı Ölçeğinde Analiz}

Bina Formu: Kaleiçi evlerinde, zemin kat sokağa uyum sağlayan bir biçimlenme gösterirken üst katlarda odalar sokağa çıkma yapmaktadır. Sıcak iklim bölgelerinde, bina yüzeyinden ısıyı uzaklaştırmak adına yapılan girinti ve çıkıntılar ile duvar yüzeyi artırılarak ısı kaybının gerçekleştirilmesi sağlanmıştır.
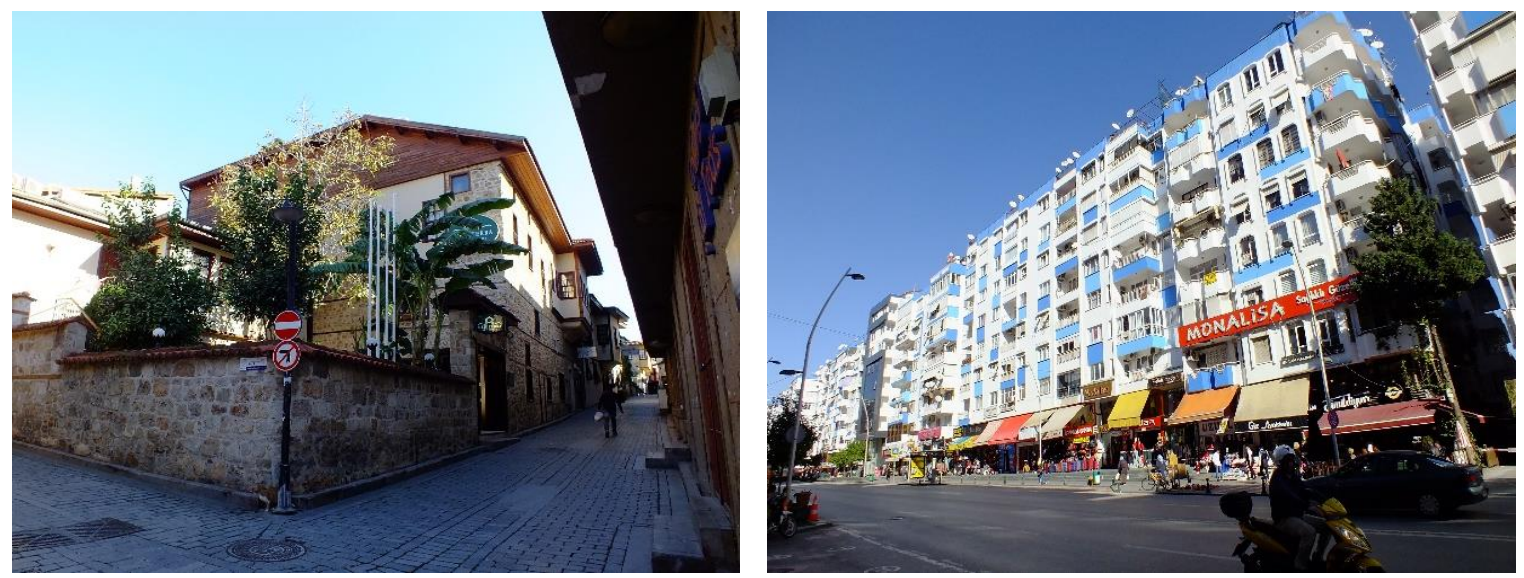

Şekil 4. Yapı-sokak ilişkisi / Solda Kaleiçi, sağda Deniz Mahallesi [26].
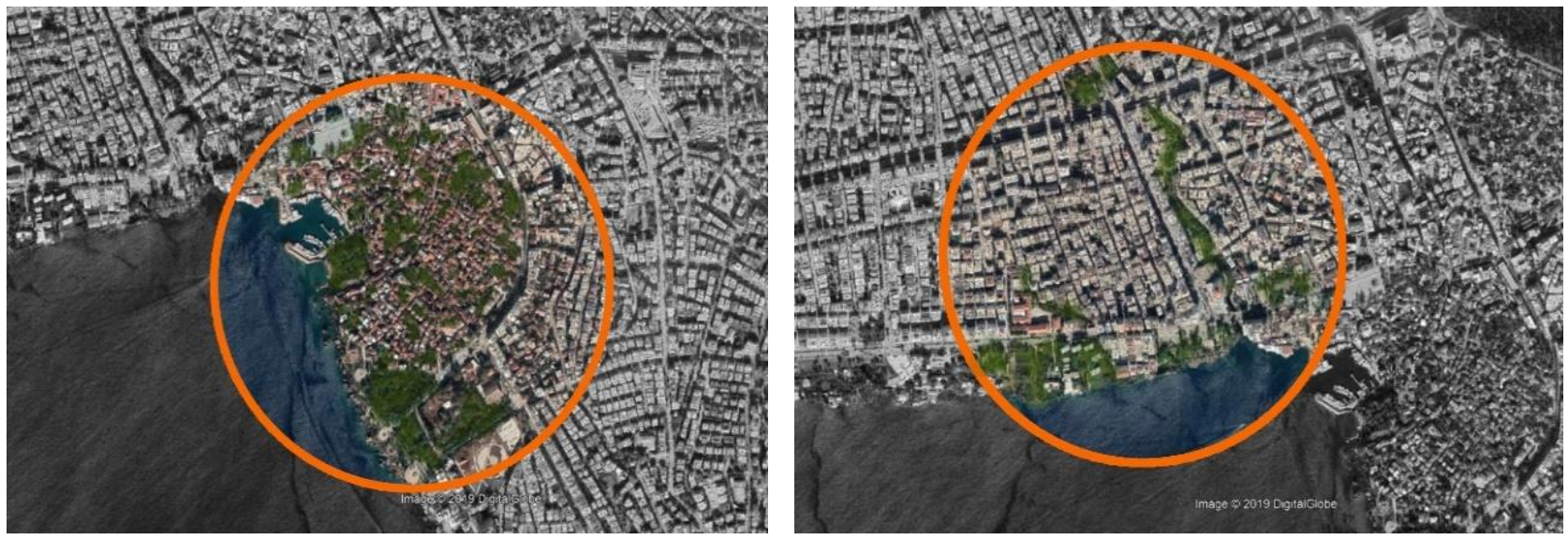

Şekil 5. Kentsel peyzaj alanları / Solda Kaleiçi, sağda Deniz mahallesi. 
Kaleiçi evlerinde 3-4 metre arasında değişkenlik gösteren tavan yüksekliği ise, mekân içindeki hava hareketini sağlamak açısından önem taşımaktadır. Yapıların çatıları kırma olup, çatı bitişlerinde ortalama 50-60 cm genişliğinde ahşap saçaklar görülmektedir. Saçaklar kışın yağmurdan korunmayı, yazın ise gölgelemeyi sağlamaktadır. Dar sokaklarda yapıların saçakları ve sokağa yapılan çıkmalar, sokak üzerini örterek, yağmurdan veya güneșin olumsuz etkisinden korunmayı sağlayan, korunaklı mekânlara dönüşmektedir (Şekil 6).

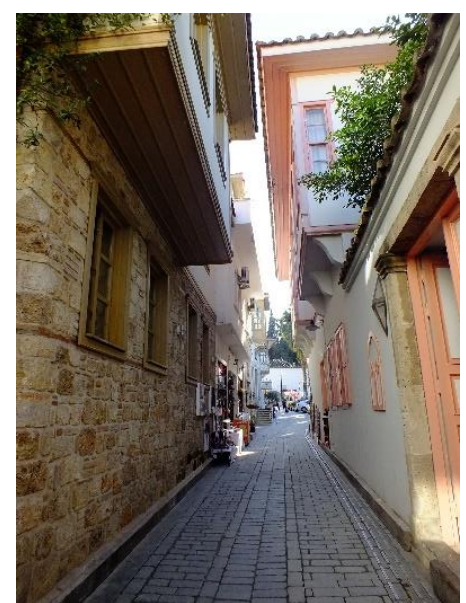

Şekil 6. Kaleiçi evlerinde sokağa yapılan çıkmalar ve saçaklar [27].

Deniz Mahallesi'nde ise yapılar genel olarak çok katlı, kompakt bir forma sahip olup, dış mekâna pencere ve kapı boşlukları ile açılmaktadır. Yapıların cephelerinde, yüzeyden ısıyı uzaklaştırmanın sağlanmasına yardımcı olan girinti ve çıkıntıların olmaması, konfor koşullarının olumsuz yönde etkilenmesine neden olmaktadır. Çağdaş dokudaki yapıların kat yüksekliklerinin ise ideal yükseklikten daha düşük olduğu gözlemlenmiştir. $\mathrm{Bu}$ durum evlerin basık olmasına neden olmuş, iç mekânda hava sirkülasyonu yeterli düzeyde sağlanamamıştır (Şekil 7).

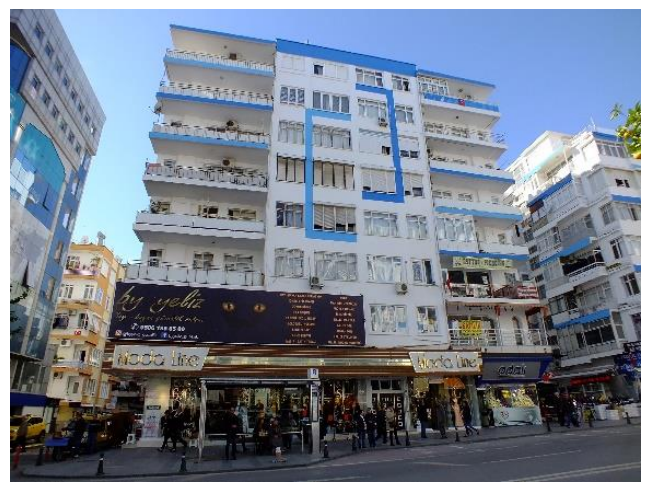

Şekil 7. Anafartalar caddesi üzerinde yer alan konutlar ve ticari mekânlar [27].

Yerleşimde yer alan konutların çatıları ise düz olarak inşa edilmiştir. Bu çatı tipi, yaz aylarında çatı altında oturan kullanıcı için konforsuz iç mekân koşullarının oluşmasına neden olurken, kış aylarında ise çatıda biriken yağmur suyu çoğu zaman çatı döşemesine zarar verebilmektedir.

Mekânsal Kullanım ve Organizasyon: Kaleiçi evleri "Batı Anadolu'da Geleneksel Konut" plan şemasını yansıtan bir mekânsal düzene sahip olup, genel olarak dış sofalı plan tipindedir. Dış sofalı plan tipinin tercih edilme nedeni ise yapının yüzey sayısını artırarak yaz aylarında ısı kaybını arttırmaktır. Genelde 2 katlı olan evlerin bazılarında bulunan ara kat, kışın soğuk günlerde kışlık kat olarak kullanılabilmektedir.

Konut içindeki mekânlar düzenlenirken iklim özellikleri dikkate alınmış, mekânlar ihtiyaçları doğrultusunda organize edilmiştir. Kaleiçi evleri sıcak iklimden dolayı içe doğru yönelmiş, bu içe yönelim avlu mekânı ile desteklenmiştir (Şekil 8). Avlu, bugün yeniden işlevlendirilmiş yapılarda aktif bir kullanım sergilemekte, avlu ile yakın ilişki içerisinde olan sofa ise yarı açık mekân kullanımı sağlayarak mekânın çeşitlenmesinde etkili olmaktadır. Odalar kuzey yönde yerleşim gösterirken, sofa ise hâkim rüzgâr yönü olan güney ve güneydoğu yönünde yer almaktadır. Sofanın çevresinde yer alan odalar ise cephede yer alan açıklıklar ve sofa arasında oluşan serin hava akımından yararlanmaktadır. Bu bağlamda çıkma yapan mekânlardaki yan pencereler çapraz havalandırmanın sağlanmasında etkili olmakta, mekânda pasif havalandırma sağlanmaktadır. Çıkmalarda yer alan açıklıkların büyük ve çok sayıda olması mekânın aydınlanması açısından da önem taşımaktadır.

Geleneksel Kaleiçi evlerinde avlularda genellikle revaklar yer almakta, bu revaklar üzeri bitkilerle ya da kiremitlerle kaplanmış şekilde karşımıza çıkmaktadır. Kaleiçi evlerinde, avlu ve yarı açık mekânların kullanımı, konut iç ve dış mekânlarının serinlemesini ve böylece daha yaşanabilir mekânların ortaya çıkmasını sağlamaktadır (Şekil 8).

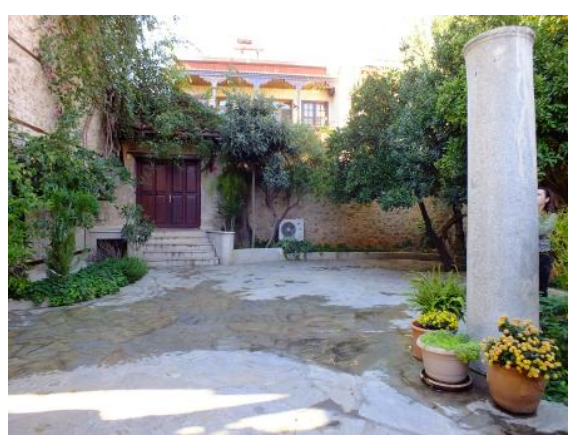

Şekil 8. Geleneksel Kaleiçi evlerinde avlu kullanımı [27].

Çağdaş dokuda ise genel olarak $3+1$ düzenlemede günümüz plan tipolojileri görülmektedir. İklim koşulları göz önüne alınmadan oluşturulan mekânsal düzenlemede tüm odalar dış ortamla temas halinde olup, odalara ulaşımın sağlandığı koridor ise iç mekânda diş ortamdan kopuk bir biçimde yer almaktadır. Geleneksel konutlarda sofanın karşılığı 

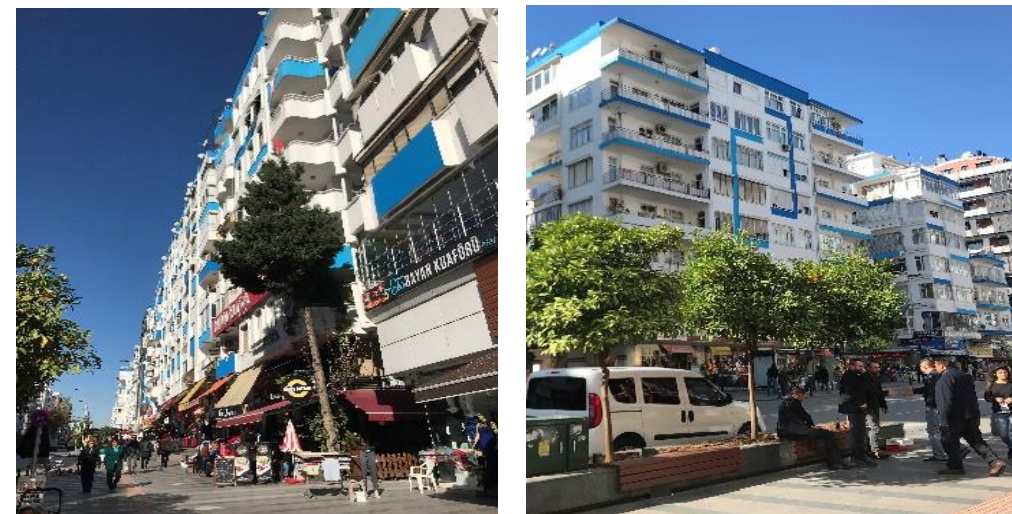

Şekil 9. Deniz Mahallesi açık, yarı açık mekân kullanımı [26, 27].
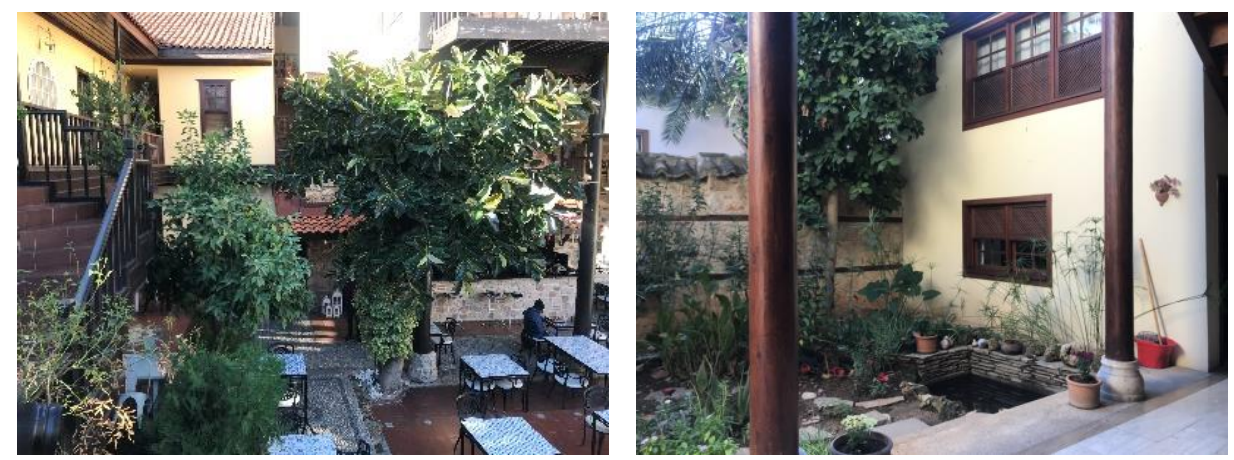

Şekil 10. Geleneksel Kaleiçi evlerinde bitkisel elemanların ve su unsurunun kullanımı [26, 27].

olarak mekânlara geçişi sağlayan koridorlar dış ortama açılamaması dolayısıyla iç mekân ve dış mekân arası geçiş elemanı olarak kullanılamamış, hava akımı yeterince sağlanamamıștır. Konutlar bireysel olmayıp, bir katta 1-4 daire olacak biçimde düzenlenmiştir. Bu bağlamda konut içinde yer alan mekânlar iklim, güneşlenme ve rüzgâr verileri göz önüne alınmadan inşa edilmiştir. Bu durum yaz aylarında hava sirkülasyonunun sağlanamamasına dolayısıyla mekânların aşırı ısınmasına, konfor düzeyinin azalmasina ve ekstra soğutma önlemlerinin alınmasına neden olmuştur. $\mathrm{Bu}$ düzenlemede yer alan konutlarda, yarı açık mekân kullanımı olarak yalnızca balkonlar görülmektedir. Konutların zemin katlarında yer alan ticari mekânların açık mekânda oturma ve yeme-içme alanları oluşturdukları, aynı zamanda yayalar için açık oturma alanlarının düzenlendiği görülmektedir. Bölgede yarı açık mekân kullanımı ise oldukça azdır. Yalnızca, güneșten korunmak için bölge esnaflarının kullandığı tenteler yarı açı mekânları oluşturmaktadır (Şekil 9).

Bitkilendirme ve Su Elemanı Kullanımı: Geleneksel Kaleiçi evlerinde avlularda ve özellikle güneye bakan cephelerde serinletme amaciyla bitkisel unsurlar kullanılmıştır. Böylece avluda, gölgeli yarı-açık mekânlar oluşturularak termal konfor ve yaşam kalitesi arttırılmaktadır. Yine aynı şekilde bina avlularında ya da dar sokak aralarında konsolos çiçekleri, erik, zerdali, palmiye ve dut gibi ağaçlara rastlanılmaktadır (Șekil 10).
Deniz Mahallesi'nde ise yoğun bir kent dokusunun bulunduğu ve yalnızca yaya yolu olarak kullanılan bölgede Anafartalar Caddesi boyunca uzanan tekil ağaçların olduğu görülmektedir. Ağaçların boyları ortalama 12-16 metre arasında değişmektedir. $\mathrm{Bu}$ bölgede su unsuru kullanımının neredeyse yok denecek kadar az olduğu görülmektedir. Yalnızca "Yavuz Özcan Parkı" ve Anafartalar Caddesi'nin kesişiminde yer alan süs havuzu dikkat çekmektedir (Şekil 11).

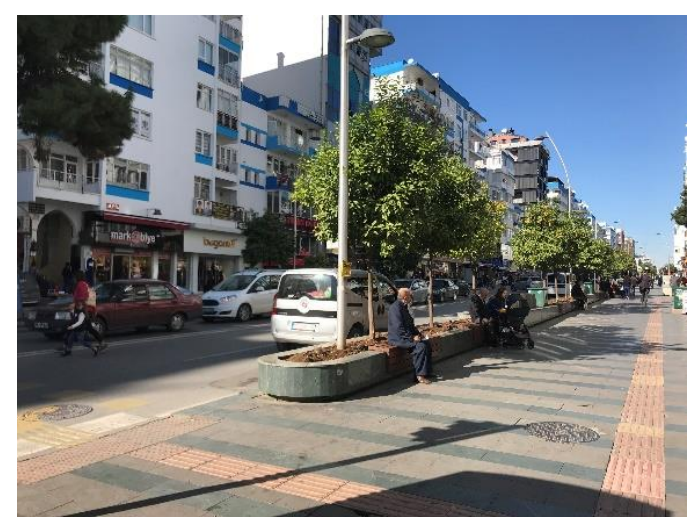

Şekil 11. Deniz mahallesi bitkisel elemanların kullanımı [26].

Bina Kabuğu: Kaleiçi evlerinde cephe elemanları olarak yüksek bahçe duvarları, giriş kapıları, cumbalar, sokağa açılan pencereler yer almaktadır. Dış sofalı plan tipolojisine sahip olan evlerde, sofa bahçe yönünde yer almakta, odalar ise sofaya birer kapıyla açılmaktadır. Üst katta yer alan odalar cephede çıkmalar yapmakta, çıkmalar üzerinde farklı yönlerde pencere açıklıkları ile çapraz havalandırma 
sağlanmaktadır. Cephe boyunca devam eden açıklıklar mekânların aydınlanması ve havalandırmanın sağlanması açısından önem taşımaktadır. Kaleiçi evlerinin bazı örneklerinde bulunan tepe pencereleri de aydınlatmanın yanı sıra iç mekândaki hava akımının düzenlenmesinde önemli rol oynamaktadır (Şekil 12). Evlerin batı yönlerinde güneş ışınlarının etkisini azaltmak ve gölgelemeyi sağlamak amaciyla sürme ahşap kafes ve ahşap kepenkler yer almaktadır. Evler genel olarak sarı tonlarında veya beyaz renktedir.

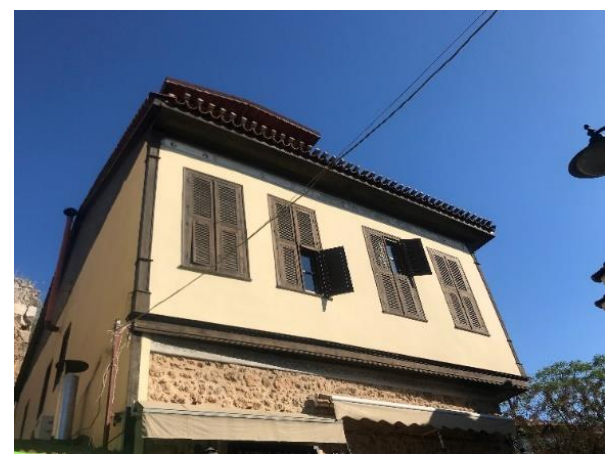

Şekil 12. Kaleiçi evleri, gölgelendirme elemanı kullanımı [27].

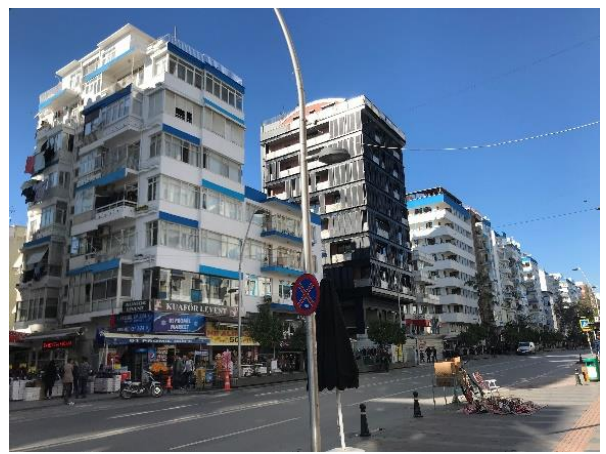

Şekil 13. Çağdaş dokuda yer alan Deniz mahallesi konutlarında cephe düzeni [27].

Çağdaş dokuda yer alan konutların bina kabuğu özellikleri değerlendirildiğinde ise cephede yer alan klima motorları ve panjurlar göze çarpmaktadır (Şekil 13). Konutların pasif iklimlendirmeye uygun biçimde cephe düzenine ve mekân organizasyonuna sahip olmaması, mekânların soğutulması için ekstra enerji harcanmasına ve ek önlemler alınmasına sebep

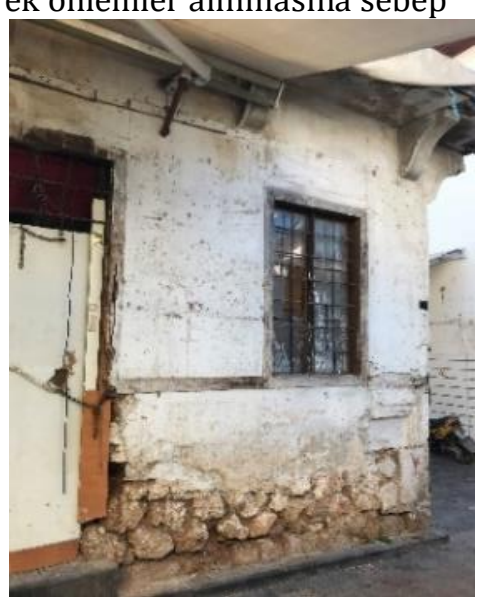

Sekil 14. Geleneksel Kaleiçi evlerinde yapı malzemesi ve yapı strüktürü [26]. olmuştur. Panjurlar yazın güneş kırıcı amacıyla kullanılmıș olsa da mekânların serin kalmasında yeterince etkin olmamaktadır. Konuttaki mekânsal düzenlemeden kaynaklı olarak odalar yan yana sıralanmış, bina kabuğunda açılan boşluklar karşılıklı hava akımı yapacak şekilde düzenlenememiștir. Bina kabuğu iç ortam ve dış ortam arasındaki dengeyi sağlamada yetersiz kalmış, konfor düzeyi düşük mekânlar oluşmuştur.

Yapı Malzemesi: Geleneksel Kaleiçi evlerinde yöreye özgü, kolay bulunabilen ve ucuz malzemeler kullanılmıştır. Zemin katlarda taş yapı malzemesi kullanılırken, üst kat strüktüründe ise ahşap malzeme harç ile birlikte kullanılmıştır. Çatı malzemesi olarak ise alaturka kiremit kullanıldığı görülmektedir (Şekil 14).

Deniz Mahallesi'nde bulunan apartman yapılarının birçoğu betonarme karkas sistem ve tuğla dolgu malzemeden yapılmıș ve üzeri sıvanmıștır. Çağdaș dokuda yöreye özgü malzemelerin kullanılmadığı gözlenmiştir. Çatıların ise teras çatı olarak yapıldıkları ve herhangi bir kaplama malzemesi kullanılmadığı görülmüştür.

\section{Tartışma ve Sonuç}

Vernaküler mimarlık örneklerinin neolitik çağdan günümüze kadar gelen oldukça zengin bir geçmişi bulunmaktadır. Bu mimari yapılanma, iklim ve arazi verilerini önemseyen, o yöreye ait malzemeleri kullanan, sosyal ve kültürel özellikler ile sürdürülebilir yapıların ortaya çıkmasını sağlayan bir mimarlık biçimi olarak karşımıza çıkmaktadır. Ancak, günümüzde artan kentleşme ve endüstrileşme ile geleneksel mimarlık örneklerinin kullanımı azalmış, ortaya çıkan yeni yapım yöntemleri ve malzemelerin kullanımı artmıştır. Kullanılan bu teknik ve malzemelerin birçoğu binaların enerji tüketiminin ve çevreye verilen zararın artmasına neden olmuştur. Nüfusun artışı ile kentlerdeki konut sayısı artmış ve bu durum çok katlı binaların inşa edilmesini de beraberinde getirmiştir.

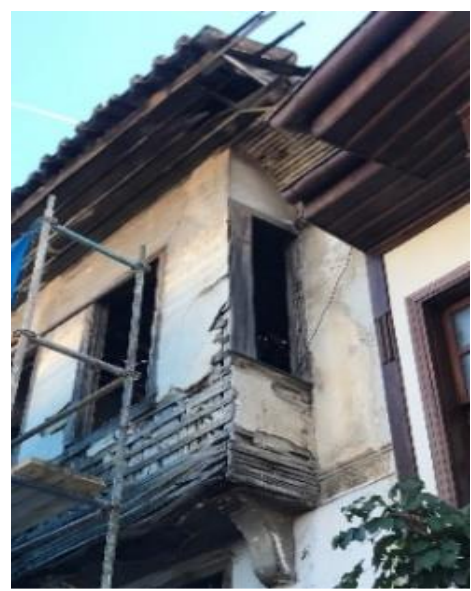


Çalışmada, Antalya kentinden seçilen geleneksel dokudaki Kaleiçi bölgesi ve 1950 sonrası imar planlı konutların yer aldığı Deniz Mahallesi, çeşitli araştırmalardan elde edilen kriterler üzerinden karşılaştırılmıştır. Ulaşılan sonuçlara göre, geleneksel dokuda yer alan Kaleiçi bölgesinin sürdürülebilirlik bağlamında manzaraya, denize ve hâkim rüzgâra yönelimi açısından daha olumlu olması, organik sokak dokusuna sahip olması, topografyaya uyumlu olması ve sokak kesitlerinin insan ölçeğinde olması gibi nedenlerden dolayı, Deniz Mahallesi'ne göre yerleșim ölçeğinde daha sürdürülebilir olduğu gözlenmiştir. Aynı zamanda, Kaleiçi bölgesindeki konutlarda, yöreye uygun malzemeler kullanılması, iç mekân ve avlularda termal konforun sağlanması, bitkisel elemanlar ve su unsurlarının kullanımı, insan ölçeğinde avlulu ya da bahçeli konutların yer alması ve doğal havalandırmanın sağlanması gibi kriterler, bu binaların çağdaş dokudaki konutlara kıyasla oldukça sürdürülebilir binalar olduğunu ortaya çıkarmaktadır. Çevre verilerine uygun tasarlanmış olması, bölgenin yerleşim ve yapı ölçeğinde sürdürülebilir olmasını sağlamıştır. Antalya'da tarihi kimliği ile önemli bir yere sahip olan Kaleiçi yerleşiminin konumu ve yönlenmesi ile sürdürülebilir kentsel tasarım anlayışına göre şekillendiği görülmüştür.

Vernaküler mimari, günümüzde ve gelecekte çevreye duyarlı mimari yaklaşımların var edilmesinde başvurulabilecek, zengin birikimler içeren bir bilgi kaynağıdır. Dolayısıyla bu binaların yeni yapılan çağdaş konutlara da örnek olması, kullanılan yapım teknikleri, malzemelerinin ve çeşitli ekolojik yöntemlerin çağdaş konutlarda da kullanılması daha sürdürülebilir ve daha konforlu mekanların ortaya çıkması açısından oldukça önem taşımaktadır. Geleneksel mimarlı örneklerinin korunması, orijinalliğini kaybetmiş binaların yeniden onarılması ve kullanımının sağlanması gerekmektedir. Aynı zamanda, vernaküler mimari yol gösterici olmalı ve sürekli yorumlanarak değişime direnç göstermeden ele alınmalıdır. Ülkemizdeki mimarlık eğitimlerinde de vernaküler mimarinin önemine değinilmeli ve bu konu ile ilgili dersler yer almalıdır.

\section{Kaynakça}

[1] Al Sayyad, N. 2006. Vernacular Architecture in the 21st Century: Theory, Education and Practice. Asquith L., Vellinga M., ed. Taylor and Francis group, SS, London and New-York, 312s.

[2] Özkan, S. 1992. Régionalisme Et Mouvement Moderne, À La Recherche d'Une Architecture Contemporaine En Harmonie Avec La CultureRegionalism And The Modern Movement, a Research of a Contemporary Architecture in Harmony With Culture. Architecture and Behaviour, 8(4), 353- 366.
[3] Bozdoğan, S. 2013. Modern Mimarlık ve Tropik Coğrafyalar, Mimarlık Dergisi, Sayı 372, http://www.mimarlikdergisi.com/index.cfm?sa $\mathrm{yfa}=$ mimarlik\&DergiSayi=386\&RecID $=3174$ (Erişim Tarihi: 11.10.2019).

[4] Gonçalves, J., Mateus, R., Fernandes, J. E. P., Ferreira, T. 2013. Tradition in Continuity: Thermal Monitoring in Vernacular Architecture of Farmsteads From Northeast Portuguese Region Of Trás-Os-Montes. Portugal SB13Contribution of Sustainable Building to Meet EU 20-20-20 Targets, 30 October-1 November, Portugal, 259-267.

[5] Zhai, Z. J., Previtali, J. M. 2010. Ancient Vernacular Architecture: Characteristics Categorization and Energy Performance Evaluation. Energy and Buildings, 42(3), 357365.

[6] Korumaz, M., Canan, F., Güleç, S.A., 2006. Evaluation of the Energy Efficiency of Gaziantep Traditional Houses. PLEA 2006- The 23rd Conference on Passive and Low Energy Architecture, 6-8 September, Geneva, 95-101.

[7] Paunovic-Žaric, S., Salihbegovic, A., Rosemann, A. L. P. 2016. Towards a Contemporary Vernacular Building Envelope. In 3rd International Conference Sustainable Architecture, May 25-27, Becici, Montenegro.

[8] Jebens-Zirkel, M., Figols Gonzales, M. 2015. Organic Architecture Based on Vernacular Heritage: The Circe Building, ss 359-364. Vernacular Architecture: Towards a Sustainable Future, Mileto, C., Vegas, F., Soriano L.G., Cristini, V., ed. 2015. CRC Press Taylor And Francis Group, Leiden, 804s.

[9] Creangă, E., Ciotoiu, I., Gheorghiu, D., Nash, G. 2010. Vernacular Architecture As A Model For Contemporary Design. WIT Transactions on Ecology And The Environment, EcoArchitecture III, 128, 157-171.

[10] Bosman, G., Whitfield, C. 2015. Perceptions of Vernacular Architecture, ss 157-162. Mileto, C., Vegas, F., Soriano, L. G., Cristini, V., ed. 2015. Vernacular Architecture: Towards a Sustainable Future. CRC press Taylor and Francis Group, Leiden, 784s.

[11] Fernandes, J., Dabaieh, M., Mateus, R., Bragança, L. 2014. The Influence of The Mediterranean Climate on Vernacular Architecture: A Comparative Analysis Between The Vernacular Responsive Architecture of Southern Portugal and North of Egypt. World Sustainable Buildings SB14, October 28-30, Barcelona, Spain, 16-22.

[12] Tawayha, F. A., Bragança, L., Mateus, R. 2016. Ecology and Environment, an Urban Scale Comparative Study Between Contemporary and Vernacular City of Nablus. SBE16 Brazil \& 
Portugal- Sustainable Urban Communities Towards a Nearly Zero Impact Built Environment, September 7-9, Vitória-Brazil, 1589-1598.

[13] Aktuna, M. 2007. Geleneksel Mimaride Binaların Sürdürülebilir Tasarım Kriterleri Bağlamında Değerlendirilmesi: Antalya Kaleiçi Evleri Örneği, Yıldız Teknik Üniversitesi, Fen Bilimleri Enstitüsü, Yüksek Lisans Tezi, 113s, İstanbul.

[14] Rupa, A., Ganguly, T. 2015. Role of Vernacular Architecture of India in Green Building Design A Case Study of Pauni. International Journal on Recent and Innovation Trends in Computing and Communication, 3(2), 130-135.

[15] Halıcıoğlu, F. 2012. Analysis of Vernacular Architecture in Terms of Sustainable Considerations: The Case of Sirince Village in Western Turkey, Alam Cipta, International Journal of Sustainable Tropical Design Research and Practice, 5(2), 39-54.

[16] Rapoport, A. 1969. House Form and Cultua. University of Wisconsin- Milwaukee PrenticeHall, Inc., Eglewood Cliffs, London, 246s.

[17] Hasol, D. 1998. Ansiklopedik Mimarlık Sözlüğü, Yapı Endüstri Merkezi Yayınları, İstanbul, 500s.

[18] Bayram, Ö. F. 2014. Doğu Karadeniz Bölgesinde Geçmişten Günümüze Vernaküler Mimari, Yıldız Teknik Üniversitesi, Fen Bilimleri Enstitüsü, Yüksek Lisans Tezi, 155s, İstanbul.

[19] Küçükerman, Ö. 1996. Kendi Mekanının Arayışı
İçinde Türk Evi. Türkiye Turing ve Otomobil Kurumu, İstanbul, 214s.

[20] Arcan, E. F., Evci, F. 1999. Mimari Tasarıma Yaklaşım, Tasarım Yayın Grubu, İstanbul,199s.

[21] Olygyay, V. 1973. Design with Climate, Bioclimatic Approach to Architectural Regionalism. Princeton University Press, Princeton, 224s.

[22] Watson, D. Kenneth Labs. 1992. Climatic Building Design Energy Efficient Building Principles and Practises. McGraw-Hill Book Company, New York, 288s.

[23] Kobya, H. B. 2017. Düşey Yeşil Cepheler Ve Yeşil Çatıların Ekolojik Kriterler Bakımından İncelenmesi Ve Enerji Verimliliğinin Değerlendirilmesi. Selçuk Üniversitesi, Fen Bilimleri Enstitüsü, Yüksek Lisans Tezi, 119s, Konya.

[24] Rudofsky, B. 1964. Architecture Without Architects. Museum of Modern Art, New York, $156 s$.

[25] Anonim, 2019. https://www.antalya.bel.tr/i/cografya (Erişim Tarihi: 05.02.2019).

[26] Kobya, H. B. 2018. Hande Büşra Kobya Fotoğraf Arşivi.

[27] Aköz, A. B. 2018. Ayten Begüm Aköz Fotoğraf Arşivi. 